\title{
Adaptation of Buyruk Manuscripts to Impart Alevi Teachings: Mehmet Yaman Dede and the Arapgir-Çimen Buyruğu
}

\begin{abstract}
Today, many Alevis believe that the central teachings of their religious tradition are represented in a book called Buyruk, or Command. In the last decades, some twenty books have been published to make the relevant texts, originally written in the Perso-Arabic alphabet of Ottoman Turkish, available for readers familiar only with the Latin-based alphabet of modern Turkish. However, too little is known about the manuscripts that served as exemplars for these printed works. The Arapgir-Çimen Buyruğu is such a manuscript, however, through its last owner Mehmet Yaman Dede, a religious specialist of the tradition, it can now be understood how variously he adapted its contents for presentation in a published version for community members eager to become acquainted with these writings. It is suggested here that his work on both text and manuscript reflects earlier practices, partly rearranged, however, and that his endeavours must be reflected in light of his life story, and his educational history in particular.
\end{abstract}

\footnotetext{
Buyruk is a living document. There is no single definitive version agreed upon by all Alevis. Numerous versions of the text exist in manuscript form. It is readily available in a variety of inexpensive published versions. Although these versions differ both in length and content, they generally contain a similar collection of narratives, descriptions of ritual, poetry, and explanations of theology. ${ }^{1}$
}

This definition of Buyruk, as presented by Vernon Schubel, alludes to major questions that are to be raised in the following. In the absence of a definitive version of Buyruk, can we assume that some scribes, compilers and others involved in the production of such manuscripts were free to make changes in order to adapt the texts to certain needs? Moreover, are there adaptations that can be linked to requirements in teaching and learning? And last but not least, how do recent print versions relate to the previously handwritten collections of texts?

1 Schubel 2010, 331.

๖ Open Access. (๐) 2021 Janina Karolewski, published by De Gruyter. (c))BY-NC-ND This work is licensed under the Creative Commons Attribution-NonCommercial-NoDerivatives 4.0 International License. https://doi.org/10.1515/9783110741124-022 
Given the different text versions in Buyruk manuscripts, it is apparent that they have been subject to adaptation from the outset. ${ }^{2}$ Indeed, it is probably fair to admit there has been a generally unstable transmission of Buyruk texts. But some manuscripts known to us thus far, display massive textual parallels. When cursorily comparing the latter, we observe a number of recurring modifications among them abbreviated or expanded text versions, but also differences in spelling or word choice. ${ }^{3}$ An ideal case, however, enabling an understanding of which scribe departed from his exemplar when copying and which copyist tried to faithfully reproduce the texts before him, is a rarity. For this reason, we have decided to focus here on an individual case in which we can compare the manuscript exemplar with the resultant adaptations, albeit in print.

Following an overview on Buyruk manuscripts and printed versions, we will introduce the Alevi religious specialist Mehmet Yaman Dede (1940-2014) , who worked intensively with written sources of his tradition. Then, we will zoom in on the Arapgir-Çimen Buyruğu, the manuscript which served Mehmet Yaman Dede as an exemplar for his printed Buyruk publications. Finally, we will analyse his adaptation strategies, which, as proposed, can be interpreted to some extent as continuations and rearrangements of practices that were already commonly employed with manuscripts.

\section{Buyruk books: From manuscripts to prints}

The Alevis are members of a marginalised religious tradition from Anatolia and other neighbouring regions, often referred to as Alevilik, or Alevism. ${ }^{5}$ In their private book collections so-called Buyruks or Buyruk manuscripts are often

2 See e.g. Karakaya-Stump 2010, 279; Kehl-Bodrogi 1997, 135; Otter-Beaujean 1997, 224; Yildiz 2017, 80.

3 The first critical Buyruk edition was accomplished by Riza Ylldırım only after the submission of the present paper (see Yıldırım 2020). We thank him for sharing parts of his, at that time, still unpublished book with us.

4 We feel deeply indebted to the late Mehmet Yaman Dede and his son Prof. Dr. Ali Yaman, Abant İzzet Üniversitesi, Bolu, Turkey, for their boundless confidence through all the years. Our research would not have been possible in this form without their support. We also express our thanks for giving the authorisation for publishing all images reproduced here.

5 For a short introduction to the Alevi tradition see Dressler 2008; and for a special focus on teaching and learning in Alevi communities, see the contribution by Janina Karolewski in the present volume (Section 'Educational Setting', pp. 151-184). 
found. ${ }^{6}$ The designation Buyruk, translated as 'command', can be understood as a label that Alevis used to apply to books belonging to a corpus or set of texts. It is said that this corpus or set contains the central religious and social teachings of Alevi communities. It seems to have been a rare exception to indicate this label within the manuscripts, either as a heading or on the cover. Buyruks, therefore, can have both identical or non-identical titles, if at all, and they can comprise similar texts, display textual differences, vary in extent and order, and so forth. ${ }^{7}$ The earliest copies are said to date back to the first quarter of the $17^{\text {th }}$ century ${ }^{8}$, but most of the recently documented manuscripts were copied between the late eighteenth and early twentieth century. ${ }^{9}$ Buyruk texts are usually composed in Ottoman Turkish, i.e. Turkish written in Perso-Arabic characters ${ }^{10}$, with occasional use of short phrases in Arabic.

Alevi religious specialists educated in the Arabic alphabet made use of these text collections to acquire knowledge themselves and disseminate it among their community members and followers. The specialists were not allowed, however, to disclose the texts to outsiders, and it is even said that access to Buyruks had been restricted to chosen, presumably male-only members of the ocaks, or holy lineages. Such esoteric codes of conduct, in part at least, are present in many Buyruks ${ }^{11}$ and are a common feature regarding mystic interpretations of Islam.

The common use of Buyruks and many other manuscript books came to an almost absolute end by the mid-twentieth century approximately. Following the establishment of the Republic of Turkey in 1923, several reforms and modernisation programmes took hold in Turkish society, severely affecting the educational practices of Alevi communities. The most significant and obvious repercussion was the conversion to the Latin alphabet, which was implemented by means of

6 For short overviews on Buyruks see e.g. Otter-Beaujean 1997; Karakaya-Stump 2010; for comprehensive analysis, see Kaplan 2010; Yıldırım 2020.

7 We suggest this understanding of Buyruk (Karolewski 2018, 81-82), which is based on the concept of multiple-text manuscripts as 'corpus organisers' (see Bausi 2010). See also Ayfer Karakaya-Stump 2010, 279.

8 On these copies see e.g. Yıldırım 2012, 178, n. 5. The earliest occurrence of the label Buyruk, however, has been attested as 1857, when the protestant missionary Dunmore reported on Alevis in larger Dersim (see e.g. Karakaya-Stump 2010, 278). It remains unclear when the label Buyruk came into being.

9 See e.g. Kaplan 2010, 43-58; Yıldırım 2020.

10 Also referred to as Arabo-Persian characters or alphabet.

11 See e.g. Kaplan 2010, 92; Karakaya-Stump 2010, 282; and the text sample in Appendix 1 and 2. 
various literacy campaigns and the introduction of public schooling..$^{12}$ Furthermore, social changes such as secularisation, industrialisation and urbanisation led to an abandoning of Ottoman Turkish manuscripts for the transmission of Alevi practices and beliefs. Many young Alevis opted for state school and university education, paving the way for well-paid jobs, especially in the civil service, thus supporting social mobilisation in manifold ways. Not only did education shift to other domains of knowledge, but Alevis left their villages for fast-growing provincial capitals and urban centres such as Ankara and Istanbul, some even migrating abroad..$^{13}$

In 1958, Sefer Aytekin was the first to publish texts from several Buyruk manuscripts in the form of a small book (Aytekin 1958), which was well-received by many Alevis, interested in what they assumed to be their written tradition. In the following years, other popular Buyruk publications in the Latin alphabet were published. ${ }^{14}$ The editors, frequently Alevis themselves, often published their own books or worked with small publishing houses specialised in such publications. Towards the late 1980s in particular, these publishing houses began to meet the demand of many young Alevis who felt the need to engage with their tradition, from which they felt they had become estranged from over the previous decades. ${ }^{15}$

Aside from the numerous popular editions and compilations that still appear to this day, growing academic interest in Buyruks has spurred further publications and editions from the early 2000s. ${ }^{16}$ The most outstanding among them, nevertheless, were those appearing in the series titled Alevî-Bektaşî Klasikleri, that is to say Alevi-Bektaşi Classics. The series was established by Türkiye Diyanet Vakfl, or Religious Foundation of Turkey, which is a subordinate to Diyanet İşleri Başkanlığı, the Presidency of Religious Affairs. ${ }^{17}$ The presidency had previously turned down requests by Alevis to receive recognition of their own religious authorities or forms of religious practice. But the situation purportedly changed in 2007, when the government initiated the so-called 'Alevi Opening' for the purpose of bringing together state officials, Alevi functionaries and specialists on the issue. ${ }^{18}$ While this process ended without any real political outcome around 2015,

12 On the Turkish language reform, see Lewis 1999, esp. chap. 2 and 3.

13 For these social transformations see e.g. Massicard 2005; Shankland 2003; Y1ldırım 2017.

14 On these publications see e.g. Kaplan 2010, 95-98.

15 Vorhoff 1998, 34-36.

16 See e.g. Bisâtî 2003; Kaplan 2010.

17 Alevî-Bektaşî Klasikleri, 15 vols, Ankara: Türkiye Diyanet Vakfı, 2007-2015. For an overview on the volumes see Kaplan 2019.

18 See e.g. Borovalı and Boyraz 2014; Özkul 2015. 
the Alevî-Bektaşî Klasikleri volumes remain its tangible product, which was both supported and criticised by Alevis. ${ }^{19}$

In the past, Buyruk manuscripts had been embedded in an educational environment that strongly depended on unwritten forms of knowledge adaptation such as oral interpretations and explanations, most probably supplied by the dedes, or religious specialists..$^{20}$ As David Shankland observed in the village where he conducted fieldwork in the late 1980s, these practices were also employed using printed Buyruk books:

[...] dedes absorb those aspects [from the Buyruk] they find interesting in their own time and recount them in the course of commentaries, yorums, on songs and poetry first sung by minstrels. The Buyruk would therefore appear to be a rich source of ideas, one that shapes the villagers' thoughts within the overall, mostly oral, traditions [...]. ${ }^{21}$

But a different situation arises when Alevis who have not yet acquired profound background knowledge consult such print editions for self-study. The language is in parts quite difficult to understand and the content too dense for many readers to digest alone, without help.

Already in the late 1990s, it was suggested that the function of such print versions is beyond that of mere reading material for knowledge acquisition: 'The book and its title, in the bookstore and in the bookshelf at home [...] demonstrate and define the presence of an identity. ${ }^{22}$ This use of printed books resembles in some ways what was at times reported by Alevis about manuscripts. The dedes are said to have exhibited books and documents to the large number of illiterate lay followers as well as ocak members or have read from them on rare occasions, and the community members related objects to their tradition and its teachings ${ }^{23}$.

\section{Mehmet Yaman Dede's education and the role of manuscript books}

Unlike many editors of Buyruk texts before him, Mehmet Yaman Dede (see Fig. 1) represents the dedes, or religious specialists, of the Alevi tradition, hence the title

19 See e.g. Weineck and Zimmermann 2019; A. Yaman 2016.

20 Olsson 1998, 200-201.

21 Shankland 2005, 312.

22 Olsson 1998, 206. See also Vorhoff 1998, 35.

23 See e.g. Karolewski 2020. 
'dede' after his name. ${ }^{24}$ Ocak Köyü, the village in Erzincan Province in Eastern Turkey, where Mehmet Yaman Dede was born in 1940, is not only home to several families with a long dede tradition, but is the centre of the Hidir Abdal Sultan Ocağ1, an Alevi holy lineage $\mathrm{e}^{25}$. For the ocaks, or holy lineages, becoming a dede was the prerogative of male members only. In Ocak Köyü, as Mehmet Yaman Dede writes in his own memories, religious specialists had plenty of books at hand:

The shelves and chests in each house of our village had been full of manuscript books that had come down from earlier centuries, were preserved as holy and read as well as interpreted by our dedes in village assembly rooms and during cem [called] worship services. Many Alevi villages, especially the villages where pirs $^{26}$ stayed, were not any different from that. ${ }^{27}$

It comes as no surprise that Mehmet Yaman Dede remembers how, at an early age, he felt inclined to read the books in Ottoman Turkish left by his ancestors. Already before he was sent to ilkokul, or primary school, in 1947 where he would be trained in the Latin script of modern Turkish, a male relative taught him the Arabic alphabet. ${ }^{28}$ As his father Hayri Dede had died when Mehmet Yaman Dede was only a few years old, he initially stayed with his mother and sister in the village after finishing primary school in Ocak Köyü and the neighbouring Dutluca (formerly Aşutka, or Ašotka in Armenian).

When he left his village for Istanbul in 1954, at the tender age of fourteen, he first worked in a shop selling grains and similar wares. In his spare time, however, he learnt Ottoman Turkish vocabulary, continued reading a variety of subjects and began to compile his own book on the Alevi tradition ${ }^{29}$. Only two years

24 In this subchapter, we make intensive use of the following published autobiographical accounts by Mehmet Yaman Dede: M. Yaman 2018; Aydın 2014a and 2014b; and <https://www.youtube.com/ watch?v=NfPGwmziwvk $>$ (accessed on 1 Aug. 2019).

25 On Hıdır Abdal Sultan Ocağı and Ocak Köyü see e.g. M. Yaman 2014; Şimşek 1993.

26 Pir is a rank in the hierarchy of Alevi specialists as well as holy lineages (A. Yaman 2004, 81-82).

27 'Köyümüzün her evinde raflar, sandıklar yüzyıllar öncesinden kalan, kutsal olarak korunan, köy odalarında ve Cem ibadetlerinde dedelerimiz tarafından cemaate okunup yorumlanan el yazması kitaplarla dolu idi. Birçok Alevi köyleri özellikle de Pirlerin bulunduğu köyler bundan farklı değildi.' (M. Yaman 2018, 188). Throughout the article we do not mark peculiarities of orthography or interpunctuation in both Ottoman Turkish and modern Turkish quotes as long as understanding is guaranteed.

28 M. Yaman 2018, 56.

29 M. Yaman 2018, 61; and <https://www.youtube.com/watch?v=NfPGwmziwvk> (accessed on 1 Aug. 2019), see video sequence 05:07-05:44. This compilation is yet unpublished. 
later, in 1956, he was permitted to attend an İmam-Hatip Okulu, or vocational high school for prayer leaders and preachers, and went on to continue his studies at İstanbul Yüksek İslam Enstitüsü, or Istanbul Higher Islam Institute, till 1967. As with many graduates from the same institute, Mehmet Yaman Dede worked most of his life as a teacher of religious education, but also taught classes such as Arabic, English and German. He served as a religion teacher at the famous Pertevniyal Lisesi in Istanbul, one of Turkey's oldest and most successful public educational institutions, and as school director and teacher at the ortaokul, or secondary school, in Dutluca. ${ }^{30}$

His higher education was initially enabled by various seniors from his village and its surroundings who lived in Istanbul. Prominent among them were Abbas Erturan (1901-1962) and his wife Güllü Ana, in whose garden house Mehmet Yaman Dede lived for eleven years. ${ }^{31}$ Abbas Erturan had left Ocak Köyü at an early age for Istanbul, and had established his business as a trader..$^{32}$ Güllü Ana was a very respected woman from the village, whose words carried weight. On her initiative, Abbas Erturan sent Mehmet Yaman Dede to an İmam-Hatip Okulu..$^{33}$ As Mehmet Yaman Dede narrated once in an interview, published on YouTube, enrolment at this school was closely related to his obligations as dede, namely to study the writings of the Alevi tradition and to teach them to his following:

\footnotetext{
Abbas Erturan, the late, said, 'Will you study? You show interest in this matter'. I said, 'Uncle, I will study, of course'. He took me away from there [, from the shop I worked at in Istanbul], [and] he enrolled me in a school. I [went and] saw, it is a İmam-Hatip Okulu in Çarşamba. What do I know? I came from the village. What means İmam-Hatip Okulu and imam and so on ...? Yet, his [, Abbas Erturan's] idea was this: There, they used to teach the old script [, that is the Arabic alphabet], they used to teach Arabic and so on. Also in our village, in Ocak Köyü, with tons, I say, in each house ... There is even a house of ours there, a neighbour of ours, a house that they call 'pasha house'. It is a mansion with four floors. On each of its floors, wheresoever, there is, um, a library, a bookcase, shelf, shelf, shelves full of volumes, manuscript books. He, Uncle Abbas, said to me ... I actually called him 'Uncle Abbas'. I loved him a lot. Well, he was a very generous man. For eleven years, he made me study. [So] he said, 'I want you to study here [at the İmam-Hatip Okulu]. Our hocas [, or religious teachers,] [and] dedes, one by one, they pass away. You at least may be educated in the future, you may help and read to us from these books and so on in the years
}

30 M. Yaman 2018, 129, 257 and 271.

31 M. Yaman 2018, 78 and 146.

32 See e.g. Şimşek 1993, 239-240.

33 Ali Yaman, personal communication, 26.12.2020; Aydın 2014 a and M. Yaman 2018, 66-67. 
to come, you may share knowledge [with us]'. This is what he thought. He was a forwardlooking man..$^{34}$

This case illustrates how parts of the Alevi community from Ocak Köyü - themselves no longer residing in the village, but in Istanbul - sensed the effects of recent social transformations and reacted to them. The financial support given by Abbas Erturan and others was vital as it secured Mehmet Yaman Dede's livelihood, for he had no family in Istanbul. Aside from which, however, the hemşehrilik networks, or networks of fellow countrymen, played another important role in Mehmet Yaman Dede's education, ensuring he was able to continue taking part in Alevi community life.

The assemblies which Mehmet Yaman Dede had attended during his years in the village and now attended in Istanbul ${ }^{35}$ were crucial for his religious training. As the son of a dede, he was allowed to be present during rituals from an early age, although usually only married couples were authorised for full attendance. Mehmet Yaman Dede recalled that the affiliated layman communities in neighbouring villages asked him to conduct their rituals, as a mere ten-yearsold. ${ }^{36}$ By then, however, he had already experienced how oral and aural transmission, combined in part with reading from books and singing poetry to instrumental accompaniment, was employed during rituals and social

34 'Abbas Erturan, rahmetli, "Sen okur musun?" dedi, "Meraklısın bu işe.”. Dedim "Dayı, okurum, tabii ki.”. Oradan götürdü beni, bir okula yazdırdı. Baktım, Çarşamba’da bir İmamHatip Okulu'dur. Ne bileyim ben? Köyden gelmişim. İmam-Hatip Okulu, imam ne demek filan ...? Oysa onun derdi şuymuş, orada eski yazı öğretilirmiş, Arapça filan öğretilirmiş. Bizim köyümüzde de, Ocak Köyü’nde, tonlarla diyeyim ben, her evde ... Hatta bir evimiz orada, bir komşumuz, ev vardır ki paşa evi derler. Dört katlı bir konaktır. Her katında, neredeyse, şey vardır, kütüphane, kitaplık, raf raf raflar dolusu ciltlerle, el yazması kitaplar. O bana söyledi, Abbas dayı, ... Zaten Abbas dayı derdim ben ona. Çok severdim. Yani çok cömert bir insandı. On bir sene beni okuttu. Dedi ki, "Ben senin burada okumanı istiyorum ki, o hocalarımız, dedelerimiz teker teker gidiyorlar, bari sen gelecekte yetişmiş olasın, gelecek yıllarda o kitaplardan filan bize yardım edesin, okuyasın, bilgiler veresin" diye. İleri görüşlü bir adamdı.' (<https://www.youtube.com/watch?v=NfPGwmziwvk〉 (accessed on 1 Aug. 2019), see video sequence 06:59-08:05). We thank Aysel Özdilek, Universität Hamburg, for her careful proofreading of our interview transcript and translation. For the sake of authenticity, we decided against polishing his speech in Turkish, but inserted additions in the translation. The punctuation, both in Turkish and the translation, is ours, added to ease understanding (an ellipsis without square brackets indicates a pause, not an omission).

35 M. Yaman 2018, 73 and 78.

36 Aydın 2014a. The case of Mehmet Yaman Dede has to be considered in the knowledge of his father's early death and how the young boy, felt it his responsibility to succeed him (see e.g. M. Yaman 2018, 56). 
gatherings. ${ }^{37}$ On these occasions, he became not only familiar with the fixed textual lore of his tradition, but also gained access to the unfixed interpretations of both written and oral texts, and learnt how dedes imparted knowledge to the community.

The educational career of Mehmet Yaman Dede reads quite extraordinarily for a member of the Alevi tradition, most of all because he attended schools specialised in Sunni Islam, the dominant interpretation of Islam in the Republic of Turkey. Many Sunnis in Turkey, especially religious authorities, do not accept several Alevi beliefs and practices as 'Islamic' ${ }^{38}$ Therefore, it is not surprising that Mehmet Yaman Dede had to face all sorts of discrimination, during his school days as well as his years as religion teacher. ${ }^{39}$ For him, however, as for many Alevis, his tradition constitutes a form of Islam, ${ }^{40}$ and, therefore, he did not see any contradiction in his Islamic theological education, as he stated in an interview: 'There must be ilahiyatçıs, or theologians, among Alevis, but under the condition of remaining Alevi. ${ }^{41}$ Additionally, Mehmet Yaman Dede emphasised how much he had benefited from extensive language training at schools and in private classes..$^{42}$ He learnt the Arabic alphabet to enable him to read Ottoman Turkish, the language of most of the written texts that circulated in Alevi communities, and, he had excellent knowledge of Arabic and Persian.

\section{Mehmet Yaman Dede's Buyruk publications}

When Mehmet Yaman Dede began publishing Buyruk texts in the early 1990s, ${ }^{43}$ several similar publications had already appeared. Nonetheless, he had good reason for publishing his own articles and books. For instance, the Buyruk manuscripts he had access to contained texts never previously published.

37 M. Yaman 2018, 52 and 58. As a five-year old Mehmet Yaman Dede started to play the longnecked lute saz and memorized poetry and liturgical songs (M. Yaman 2018, 47).

38 See e.g. Pehlivan 1993; A. Yaman 2015. On the historical background see e.g. Dressler 2005. 39 M. Yaman 2018, passim.

40 Alevis have different understandings of their tradition today. Among the many differences some see it as a form of Islam, others interpret it as an independent religion or a non-religious lifestyle.

41 'Aleviler’den de ilahiyatçı olmalıydı, Fakat Alevi kalmak şartıyla.' (Aydın 2014a).

42 See e.g. Aydın 2014a.

43 See e.g. MAAKMDK 2000; M. Yaman 1994; and Mehmet Yaman Dede’s series of articles in CEM: Aylık Siyasi Kültürel Dergi from 1991 till 1993. 
Furthermore, he was not overly happy with the work of previous editors; ${ }^{44}$ a matter clearly related to his own curriculum vitae and occupation as teacher. And last but not least, Mehmet Yaman Dede was able to reach a wide Alevi readership with his publications both in Turkey and abroad.

From early on, Mehmet Yaman Dede was heavily involved in defining and negotiating how Alevis could maintain their tradition amidst rapid social transformations. According to him, the Alevi tradition performed an adaptation (adaptasyon) to the urban setting, and publications on Alevism, including Buyruks, were part of this process. ${ }^{45}$ As Refika Sarıönder underlines regarding Alevilik'te Cem ('The Cem Ritual in Alevism'), ${ }^{46}$ a manual Mehmet Yaman Dede had compiled, the hope was for his publication to enable Alevis (re)acquire their ritual practices by reading before they could return to mimetic forms of transmission. ${ }^{47}$ For the purpose of mediating or imparting knowledge, Mehmet Yaman Dede did not rely purely on printed publications, but strongly advocated attending courses at Alevi associations. He himself led countless of these courses, which had their beginnings in Turkey, but then also took place in Alevi communities abroad, such as in Germany, France, the Netherlands and England. After his retirement, Mehmet Yaman Dede devoted even more time than before to these educational initiatives, which he considered his duty to the Alevi community. ${ }^{48}$ The opening statement in his last Buyruk book from 2000, which was published in Mannheim, Germany, reads accordingly:

This book, which is a classic work of the Alevi belief and culture, is been presented in order to be used in Alevism courses or in schools that are to be opened in all Alevi cultural centres, [dervish convents, called] dergahs, associations, foundations, and [houses of worship, called] cemevis. ${ }^{49}$

Mehmet Yaman Dede persistently encouraged the Alevi community as a whole to start schooling their members. He saw it as necessary for Alevis to compensate for the loss of former educational institutions and practices or at least partly revive them..$^{50}$ The Alevi courses and schools Mehmet Yaman Dede had in mind,

44 See e.g. M. Yaman 1994, 38; MAAKMDK 2000, XIV-XV.

45 MAAKMDK 2000, $x$.

46 M. Yaman 2003.

47 Sarı̈nder 2005, 169-172.

48 See e.g. M. Yaman 2018, 286-303.

49 'Alevî inanç ve kültürünün klâsik bir yapıtı olan bu kitap, tüm ALEVÎ KÜLTÜR MERKEZLERİ, DERGÂHLARI, DERNEKLERİ, VAKIFLARI ve CEMEVLERİ'nde açılacak ALEVÎLIK KURSLARI ya da okullarında yararlanılmak için sunulmuştur.' (MAAKMDK 2000, inside title page).

50 See e.g. M. Yaman 2018, 206-207. 
may be understood as new forms of previously common educational settings such as social and ritualised gatherings.

It appears that when Mehmet Yaman Dede published Buyruk texts he never questioned the Alevi religious hierarchy or worried about its diminution, and made them accessible to a wide audience. The laymen who had been present at regular reading sessions from Buyruks in the past had indeed also acquired considerable insights into such text collections. Nevertheless, they relied on dedes to interpret and contextualize the text passages when read to them; this necessity persists, even though laymen are literate and can read the printed Buyruks.

Among the possible readership of Buyruk prints are undoubtedly a number of Alevi religious specialists lacking access to the written texts of their tradition largely because their families did not possess the relevant manuscripts or they were unable to read the Perso-Arabic alphabet. Precisely this loss of knowledge was of major concern to Mehmet Yaman Dede, and he openly expressed his worries that numerous Buyruk texts had not been transferred from Ottoman Turkish to modern Turkish. ${ }^{51}$ Indeed, it is claimed here that Mehmet Yaman Dede - as well as other editors before him - focused mainly on adapting Buyruk texts to modern Turkish and its Latin alphabet. Clearly these adaptations were greatly needed for the transmission of the textual knowledge preserved in Buyruks and many other manuscript books. A note left by Mehmet Yaman Dede in one of his Buyruk manuscripts emphasizes this very significance:

When Adile Bacı, the wife of dear (Uncle) İsmet Taner from Çimen, died, I recited the Qur'an. In the talk following my recitation, he [i.e. İsmet Taner] gave me [this manuscript] and said: 'The Buyruk of Safi is the Alevi foundation; there is everything [in it]. I give it to you as a gift. I grew old. It should be yours. But may you translate all of it [into Turkish]'. ${ }^{52}$

51 M. Yaman 1994, 38; and 2018, 184-190.

52 'Çimenli Sn. İsmet Erdan (amca), eşi Adile bacının ölümünde okuduğum Kur’ân sonundaki sohbette "Safi Buyruğu علو [sic] temelidir, herşey vardır. Bunu sana armağan ediyorum. Ben ihtiyarladım, senin olsun. Amma, tümünü çeviresin” diye bana verdi.' (handwritten note on a card inserted in MS 1, signed by M. Yaman, dated 7 Aug. 1995). By mistake, Mehmet Yaman Dede confused the family name of the owner; it is 'Taner' and not 'Erdan'. Later, he repeated the wrong family name occasionally (see e.g., Aydın 2014b). Thanks to Ali Yaman, this lapse has been explained (personal communication, 27 Feb. 2020) and the correct name has been used in the translation above. 


\subsection{The Arapgir-Çimen Buyruğu}

Mehmet Yaman Dede received this manuscript in August 1995, and it was crucial for his editorial work on Buyruk texts. Already in June 1991, he had acquired a photocopy of the manuscript, indicated by a note he signed and dated: 'This photocopy was made from the manuscript copy of İsmet Taner from Çimen. ${ }^{53}$.

Çimen is an Alevi village, located approximately fifteen kilometres to the South-East of Ocak Köyü as the crow flies..$^{54}$ When Doğan Kaplan wrote about the same manuscript in 2010, he named it Arapgir-Çimen Buyruğu, arguing that its owner İsmet Taner was from Çimen..$^{55}$ The Arapgir-Çimen Buyruğu is a copy of several texts with a final colophon, dated 11 Rebiülahir $1241 \mathrm{AH}$ (22 November $1825 \mathrm{CE}$ ) on fol. $118^{r}$. Although the names of the scribe and the possessor appear in the colophon, there is no mention of their descent or the place of copying. The collection

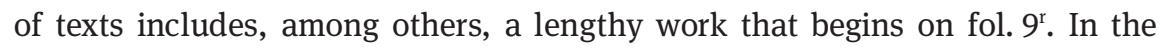
Arapgir-Çimen Buyruğu, this work is titled 'Kitāb-i Makāam-i Menāḳıb-i Şerīf-i Kuțbu l-'Ārifin Hażret-i Şeyh Seyyid Șafi' ('The Book of the Place of the Sacred Deeds of the Chief of the Knowledgeables, the Exalted Şeyh Seyyid Safi'), but appears under different, yet similar titles in other manuscript $s^{56}$. In the following, it will be referred in short as 'The Book of Sacred Deeds'.

As mentioned in the quote above, İsmet Taner is said to have referred to the manuscript copy or its text collection as 'Buyruk of Safi'. Indeed, as we have observed, it is very common today to apply short titles such as 'Safi Buyruğu' or 'Şeyh Safi Buyruğu' for the work in question; and some use such titles as labels for manuscript books containing this work. It is commonly agreed that the core of 'Şeyh Safi Buyruğu' is a dialogue between Şeyh Safiyyüddin Erdebili, the founder of the Safavid Order, and his son Şeyh Sadreddin. This conversation between father and son - as well as master and disciple - serves as a model for tuition on the central teachings of the mystical path.

53 'Bu fotokopi Çimenli İsmet Taner'in nüshasından alınmıştır.' (MS 1-XEROX, fol. $1^{\mathrm{r}}$ ).

54 At an administrative level, Çimen is a mahalle ('neighbourhood') of the Arapgir district, Malatya province since several years. The village comprises of its main settlement and a small hamlet named Ballıca. For these and all following details on Çimen, we are highly indebted to Ali Yaman, Bolu, Turkey, who obtained this information and shared it with us (personal communication, 14 and 27 Feb. 2020).

55 Kaplan 2010, 51. Ayfer Karakaya-Stump names the same manuscript Buyruk-Erzincan, explaining that it comes from an Alevi dede family from Erzincan (Karakaya-Stump 2012, 371). She probably refers to the Yaman family and Ocak Köyü. Karakaya-Stump as well as Kaplan accessed the copy when it was in Mehmet Yaman Dede's hands.

56 For several title versions see e.g. Kaplan 2010, 43-54. 
Before Mehmet Yaman Dede acquired the Arapgir-Çimen Buyruğu in 1995, the book may have remained for several years within a circle of owners all connected to the same village, namely Çimen. İsmet Taner put his ownership note under the original colophon of the copy, presenting himself as the second owner of the manuscript $\mathrm{t}^{57}$. However, İsmet Taner must surely have been aware he was not the second owner. He left other notes directly above an older and partly erased ownership note (see Fig.2), informing that the manuscript was in possession of another individual from Çimen in the $1910 \mathrm{~s}^{58}$. Hence it is possible that this Buyruk copy circulated for a minimum of eighty years among owners of the same village.

This is intriguing, for the inhabitants of Çimen are Alevi laymen related to the holy lineage of Şeyh Hasan from the village Onar, located circa ten kilometres South as the crow flies. ${ }^{59}$ As is already known from other Alevi communities, older villagers from Çimen can still recall today how family members had received education for the purpose of reading the Qur'an and reciting prayers in Arabic ${ }^{60}$ It is possible these literate lay followers obtained access to Buyruk copies, although it is usually believed to have only been the prerogative of dedes. As religious specialists came to Çimen from the nearby village Onar, it may be discounted, for now, that laymen in Çimen took on duties normally reserved for dedes.

Unfortunately, we have no information from contemporaries or their descendants telling how its owners from Çimen used the Arapgir-Çimen Buyruğu. The manuscript itself hosts four 'guest texts', ${ }^{61}$ but discloses only one piece of

57 'Its second owner, your humble servant İsmet Taner from Çimen Köyü, [sig.:] İsmet Taner' ('İkinci șāḥibi Çimen Köyünden el-fakirir 'İșmet Țaner [sig.:] İsmet Taner’) (MS 1, fol. 118').

58 'The humble owner, Çimen village, ..., son of ..., my sovereign ..., in 21 ... year 1331.' ('Șāhịibü l-fakīir Çimen ḳaryesi ... zāde hünkārım ... fì 21 ... sene 1331') (MS 1, fol. 118v). It is not possible to fully decipher the date; thus, it could be $1331 \mathrm{AH}$ (1912/1913 CE) or 1331 maliye (1915/1916 CE). In addition, another documentary note on the front flyleaf relates to Çimen Köyü; although it appears someone has tried to erase the note, it is still partly legible: 'Çimen village ... Mehmed Efendi's ...' ('Çimen ḳaryesi ... Meḥmed Efendīniñ ...') (MS 1, fol. Ir).

59 In Ballıca, however, a hamlet of Çimen, families settled there that belong to the İmam Zeynel Abidin Ocağı. They are said to have migrated from the village Mineyik (today Kurudere), the centre of their holy lineage, located some 35 kilometres as the crow flies to the South-West. (Ali Yaman, personal communication, 14 Feb. 2020).

60 Ali Yaman, personal communication, 14 Feb. 2020.

61 The four Ottoman Turkish 'guest texts' appear to be by three different hands. So far, it can only be posited that they were added before 1994, as all are present in Mehmet Yaman Dede's photocopy. On the front flyleaf are a poem with the opening line 'Çok fikir etdim hạayāle daldım / Ḥaḳḳa adam da evlādımız bildim gaāzīler’, which is presumably attributed to Divli (MS 1, fol. Ir), 
evidence directly related to the use of its text collection by someone from Çimen. On fol. $1^{\mathrm{r}}$, reads the following: 'The punishments for ill-treatment are explained on page 81 and $82^{\prime} .{ }^{62}$ The person who left this note may have been particularly interested in the sentences and fines for acting against the rules of the mystical path. To conveniently consult this text section again, the person may have found it useful to note down the relevant page numbers. Similarities in handwriting indicate that İsmet Taner wrote this note and added page numbers to the book. ${ }^{63}$ This, however, and the other few additions to the manuscript are the only traces of its users and owners before Mehmet Yaman Dede worked upon it himself.

\subsection{The work with the manuscript}

The lack of users' notes in the Arapgir-Çimen Buyruğu is not an exception but something quite common when researching the Buyruk manuscripts. Users' additions providing hints on how the books were used are rare. Mehmet Yaman Dede, however, left numerous notes; he summarized text sections in a few words, marked names and terms, or documented his own work and involvement with the original volume (see e.g., Fig. 3) and its photocopy (see e.g., Fig. 4). In addition, he marked text sections that he published later in the magazine CEM Dergisi and his book Erdebili Şeyh Safî ve Buyruğu. In the latter, Mehmet Yaman Dede utters his intent to publish the entire text of the consulted manuscript copy in the very near future. ${ }^{64}$ After having received the original volume in August 1995, he finally began his task of rendering all texts from the Arapgir-Çimen Buyruğu to Turkish, leaving a note on the last folio of the manuscript, dated 22 June 1996: 'NOTE: First, I have finished carefully reading it once from beginning to end in

and two poems of the Düvazdeh İmam kind (MS 1, fol. Iv). The first Düvazdeh İmam with the opening line 'Ḥaḳk Muhamammed 'Alī geldi dilime / ḳalma günāhıma mürüvvet yā 'Alî’ is attributed here to Kul Himmet, and the second one with the opening line 'Ey Hoca-i Hুı̣ır șıġındım șaña / birliğin hakḳkıçün bağışla bizi' misses the last lines, which may have been on the now missing first folio (see note 63 in this contribution). The fourth 'guest text' is a short note about a ritual sequence on fol. $30^{\mathrm{v}}$, a blank page, which the scribe skipped for unknown reasons.

62 '81 șahịife 82'de sitām [read here: sitem] ḥaḳḳı ta 'rīf edilir' (MS 1, fol. $1^{r}$ ).

63 It is assumed İsmet Taner added the second set of page numbers, all written with a lead pen. He may have considered it necessary, since the previously inserted set of page numbers in the utmost outer corner on the top of the pages are barely legible due to creases and fading. Further, the page number on fol. $1^{\mathrm{r}}$ is ' 2 ', with which İsmet Taner did not agree, thus began with ' 1 '. The manuscript most likely had a 'frontispiece folio', but this folio was already missing when İsmet Taner renumbered the pages.

64 M. Yaman 1994, 152, n. 1. 
order to translate it all into Turkish. Now it is time to translate it into Turkish. In the village [Ocak].' (see Fig. 2). ${ }^{65}$

From June 1996 onwards, Mehmet Yaman Dede left at least twenty-eight notes in the margins of the Arapgir-Çimen Buyruğu and marked how far he had proceeded each day he translated the text. After he had worked intensively during his stay in Ocak Köyü that summer, he returned to Istanbul in September 1996 and continued almost a year later, in May 1997 (see fols 62 and 63'). As he placed his last dated mark on fol. $74^{\mathrm{r}}$, in the second third of the manuscript, in June 1997, it is not known when he finished translating the last third, but the publication in which he finally presented his translation appeared in 2000 with the title Buyruk: Alevî İnanç, İbadet ve Ahlâk Illkeleri (Buyruk: The Principles of the Alevi Belief, Worship and Ethics) ${ }^{66}$.

In his publications, Mehmet Yaman Dede does not discuss how he proceeded when adapting Buyruk manuscripts to print, regarding script, language, or layout. Before he published Buyruk texts, however, he had already had years of experience with such kind of work. In 1965, he prepared a modern Turkish version of 'Gülzar-i Haseneyn' ('The Rose Garden of İmam Hasan and İmam Hüseyin'), which remained unpublished ${ }^{67}$, and in 1976, his translation of the Ottoman Turkish divan by the famous Sufi poet Seyyid Nizamoğlu (d. 1601) appeared ${ }^{68}$. Moreover, although it is known he used other Buyruk manuscripts available to him, there is but little knowledge of them. ${ }^{69}$ One copy belonged to Yamakzade Seyyid Mehmed Dede (d.1930), his great-grandfather, who copied the text collection during his visit in 1880 to the Bektaşi convent in what is today Hacıbektaş. ${ }^{70}$ Another copy belonged to the Babagil family from Ocak Köyü, also members of the Hıdır Abdal Sultan Ocağı. In an interview Mehmet Yaman Dede estimated the manuscript age to be 250 years. ${ }^{71}$

65 'NOT: Komple Türkçeye çevirmek için önceden bir kez baştanbaşa dikkatle okuyup bitirdim. Şimdi sıra Türkçeye çevirmede. Köyde.' (MS 1, fol. 118v).

66 MAAKMDK 2000.

67 M. Yaman 2018, 119.

68 Seyyid Nizamoğlu 1976.

69 See the following note by Mehmet Yaman Dede in MS 1-XEROX, fol. $1^{\mathrm{r}}$ : 'Note: Pages one to two that must have preceded are missing. For the entirety see the Buyruks that are with M.Y.' ('Not: Bundan önce olması gereken 1-2 sh. yok. Tamamı için bk. M.Y. deki Buyruklar.').

70 Aydın 2014b; MAAKMDK 2000, 203; M. Yaman 2018, 35-36.

71 Aydın 2014b. It is assumed that this copy is the manuscript labelled ' $Y 3$, Kemaliye-Ocak, Mustafa Kızılkaya Nüshası' in Yıldırım 2020, 269-273. On the copy by Mustafa Kızılkaya, see M. Yaman 2018, 190. 
As we have no access to these other Buyruk manuscripts, great care is to be taken in assessing the changes occurring between the texts from Arapgir-Çimen Buyruğu and Mehmet Yaman Dede's translation. Although he stated that the Buyruk texts he published were derived from İsmet Taner's book, one can see how Mehmet Yaman Dede noted textual parallels between the Arapgir-Çimen Buyruğu, his great-grandfather's copy, and a second copy from the Babagil family ${ }^{72}$. Therefore, it is quite probable Mehmet Yaman Dede occasionally used wording from other manuscripts. Furthermore, it must be remembered here that Mehmet Yaman Dede wrote by hand his entire life and prepared his several translations of Buyruk texts in the form of manuscripts, to which we have no access. Mehmet Yaman Dede certainly had his own ideas on how to adapt the manuscript for print, whether in terms of book layout, text structuring, or paratexts, as he had long been involved in publishing. Nonetheless, some of these adaptations may also be referred back to the respective publishers.

\subsection{The adaptation strategies}

In the notes left in Arapgir-Çimen Buyruğu, Mehmet Yaman Dede refers to his work as çeviri ${ }^{73}$, a term usually denoting interlingual translations, but also commonly used for the more unique instance of intralingual translations from Ottoman Turkish to modern Turkish ${ }^{74}$. The rewording of Ottoman Turkish texts into modern Turkish, which includes changes in vocabulary, grammar, syntax or style, is often termed 'translation into today's language' ('bugünün diline çeviri') or 'translation into today's Turkish' ('günümüz Türkçesine çeviri') ${ }^{75}$. Accordingly, Mehmet Yaman Dede appears on the inside title page of his 2000 Buyruk publication as 'the translator into the Turkish of our days' (literal translation of 'günümüz Türkçesine çeviren'). Indeed, çeviri also refers to the transfer of a text from one writing system to another, which Mehmet Yaman Dede also accomplished when exchanging the Perso-Arabic for Latin characters. But he did not limit his work to mere transcription, for here and there he made linguistic, lexical and content-related adjustments.

72 'See Yamak Copy p. 43' ('bk. Yamak Nüshası sh. 43') (MS 1, fol. 32'); and 'See at Babagil p. 22' ('bk. Babagil'de sh. 22) (MS 1-XEROX, fol. 9"). The second Babagil copy is most probably 'Y2, Mehmet Yaman Nüshası' in Yıldırım 2020, 265-268.

73 See MS 1 , fols $19^{\mathrm{v}}, 20^{\mathrm{v}}$, and $58^{\mathrm{v}}$.

74 See Berk Albachten 2015.

75 Konar 2019, 30. 
The most obvious difference between the Arapgir-Çimen Buyruğu and Mehmet Yaman Dede's various print publications is the layout. The prose text in the manuscript is written consecutively without punctuation marks with the poems arranged in columns; for emphasis, orientation or decoration purposes some words, phrases, and bullet point-like graphic symbols are written in red ink (cf. Fig. 5). For the print publications, Mehmet Yaman Dede decided to arrange the text in paragraphs, but did not only implement the text divisions as present in the manuscript; but at some other junctures in the text also inserted paragraphs (cf. Fig. 6). Particularly regarding long passages written in continuous text, he splits the text into several paragraphs. Noteworthy also, is how Mehmet Yaman Dede uses punctuation marks to divide phrases or mark indirect speech. We believe all this was done to make for a clearly arranged text, suitable for readers accustomed to the layout conventions and text structuring of printed books.

In addition, Mehmet Yaman Dede introduced headings for prose passages and poems, which had not existed previously in the Arapgir-Çimen Buyruğu. The choice for new paratexts clearly relates to his overall aim to add more structure to the text and to facilitate orientation. His notes on the photocopy and in the margins of the original manuscript make it clear how Mehmet Yaman Dede gave short key words to text passages, which partly turned into headings in his translation. For those parts of the text collection in which Şeyh Sadreddin poses questions to his father and master Şeyh Safiyyüddin, Mehmet Yaman Dede usually extracts the heading from the opening interrogative sentence of a passage. In creating poem headings, he usually picked a line or a part of a line from the relevant poem, either from the first, last or any other couplet (cf. Fig. 6). Most probably, he appreciated those lines or perceived them as a central message of the poems, which in turn relate to the prose text. As the poems in question did not have titles nor were handed down with titles, Mehmet Yaman Dede was not able to use titles as templates for the headings. The scribes or compilers of manuscripts that came before him were in the same situation. A few poems from Arapgir-Çimen Buyruğu also have headings, but only mention the poet's name, e.g., 'Poem by Teslim Abdal' ('Deyişat-i Teslīm Abdal') (MS 1, fol. 114'r).

The matter of titles is indeed intricate, for only a few of the headings in the Arapgir-Çimen Buyruğu are titles easily perceived as inseparable parts of the accompanying text units. These are, first of all, the headings presenting book titles: 'The Book of the Sermon of the Twelve Imams' (fol. $1^{\mathrm{v}}$ ) and 'The Book of the Place of the Sacred Deeds of the Chief of the Knowledgeables, the Exalted Şeyh Seyyid Safi' (MS 1, fol. $9^{\mathrm{r}}$ ). From fol. $70^{\mathrm{r}}$ onwards we find several headings and 
phrases, usually written in red ink, which could be titles to shorter independent text units, and some may still belong to the previous text units. ${ }^{76}$

The phrase written in red ink on fol. $70^{\mathrm{r}}$ reads as follows: 'and after this, it should be known that this is the letter that Seyyid Abdülbaki Efendi of the Sublime Lodge sent to the believers of pure faith, who are friends of the saints,' ('dahi bundan șoñra ma'lūm ola ki dergāh-i 'âlīde Seyyid 'Abdülbākị Efendīniñ evliyāya muhị olan mü'min-i pāk i'tikāālara gönderdüği mektūbdur'). Mehmet Yaman Dede not only recognised this phrase as start of a new text unit but named it 'Small Buyruk' ('Küçük Buyruk'), with a footnote explaining that all previous text parts belong to the 'Great Buyruk' ('Büyük Buyruk'). ${ }^{77}$

In 1963, Abdülbaki Gölpınarlı first claimed that Alevis distinguish between the 'Great Buyruk', (the 'Book of Sacred Deeds'), and the 'Small Buyruk', (the 'Letter by Seyyid Abdülbaki' for short).$^{78}$ Nowadays, all scholars working on Buyruks question this claim, for which Gölpınarlı provides no substantiation. ${ }^{79}$ KarakayaStump also refutes it, for 'there is nothing in the manuscript or in Alevi oral culture to warrant such an identification' ${ }^{80}$ Mehmet Yaman Dede, however, used both denominations on several occasions ${ }^{81}$ and it cannot be decided to what extent his wording was influenced by Gölpınarl. It is remarkable, however, that Mehmet Yaman Dede also mentions the Buyruk books being referred to as 'Great Buyruk' in Ocak Köyü. ${ }^{82}$

Regarding other changes Mehmet Yaman Dede made, we can say that they often relate to language, grammar, lexis, or even content, all very common to intralingual translations. To illustrate these changes, we have chosen a short passage from Arapgir-Çimen Buyruğu, juxtaposed it with the relevant part by Mehmet Yaman Dede and added our English translation (see Appendix 1 and 2 at the end

76 In understanding Buyruk manuscripts to be evolving text collections, titles, headings, or subheadings are considered dynamic in terms of each individual copy. For further comment see Karakaya-Stump 2010, 279.

77 M. Yaman 1994, 118; MAAKMDK 2000, 148.

78 Gölpınarlı 1963, 86.

79 Kaplan 2010, 101; Karakaya-Stump 2010, 281; Ylldırım 2019, 466 n. 65. As with Yıldırım, it is suggested here that the 'Book of Sacred Deeds' ends only after the 'Letter by Seyyid Abdülbaki' with the short passage on fol. $72^{\mathrm{r}}$ (see Appendix 1). This passage resembles texts that usually precede colophons or merge into them, and indeed, a scribe's colophon is present after the respective passage in another Buyruk copy (MS 2, fol. $158^{\mathrm{v}}$ ). Interestingly enough, this colophon includes an older date of copying, most probably copied by the scribe from the exemplar, before adding his own. For a similar instance in a different manuscript, see Yıldırım 2019, 480.

80 Karakaya-Stump 2010, 281.

81 See e.g. Aydın 2014a; M. Yaman 2018, passim.

82 Aydin 2014b. 
of this contribution, and see also Figs 5 and 6). In the following, all line numbers given refer to the appendices, if not marked differently.

As Mehmet Yaman Dede aimed at rewording the Ottoman Turkish texts into modern Turkish, he was able to avoid some problems that scholars usually face when preparing transliterations. On the one hand, Ottoman Turkish texts in Perso-Arabic characters are often 'under-specific' in regard to several sounds, and many vowels can even remain unrecorded if vocalisation signs are missing, as is usually the case. On the other hand, some Ottoman Turkish texts, although copied at a later period, preserve earlier common vocalisation or spelling habits. ${ }^{83}$ Without bothering to reconstruct the outdated phonetics of the texts, Mehmet Yaman Dede almost always used the written standard of modern Turkish as defined by the Turkish Language Society, or Türk Dil Kurumu.

He employed, for instance, the labial vowel harmony in cases such as the genitive (e.g., menāḳıbınuñ > menakıbının, ${ }^{84}$ 'ilminüñ > ilminin, see 1l. 10, 11) and the definite past participle (e.g., oldiğ > olduğu, bilmedüğin > bilmediğini, see 11. 11, 19). In other cases, he updated the vocalisation of words to their present spelling (e.g., deñlü > denli, içün > için, see ll. 11, 12).

Mehmet Yaman Dede also adapted peculiarities of Ottoman Turkish grammar to modern Turkish grammar. One such peculiarity is the abbreviated accusative after the third person possessive suffix (e.g., edebin ve erkānın > edeb ve erkanını, bilmedüğin > bilmediğini, see 11. 7, 19). The abbreviate accusative is not too common anymore, and as the texts in Arapgir-Çimen Buyruğu are in parts quite dense, we assume that Mehmet Yaman Dede intended to facilitate understanding by dissolving this form. Another peculiarity of Ottoman Turkish grammar Mehmet Yaman Dede partly removed from the text is the izafet construction, used to create genitive compounds or attributive connections. As the izafet construction was almost exclusively employed with loanwords from Arabic and Persian, Mehmet Yaman Dede not only dissolved these compounds, but also introduced Turkish words in their place (e.g., muhibb-i evliyā > erenlere [read here: evliyaya] muhib, and kitāb-i menāḳıb-i şerīf > kutsal buyruk [read here: şerif menakıb] kitabı, see 11. 7-8, 20-21). In modern Turkish, a considerable number of fixed izafet expressions still exist, and therefore Mehmet Yaman Dede kept phrases, which are particularly common in the religious register of Turkish (e.g., Masum-i Paklar, see 1. 15; and Hazret-i [...], Ehl-i Beyt, mürşid-i kamil, see MS 1, passim).

83 See e.g. Boeschoten 1988; Schmidt 2019.

84 The first mentioning before ' $>$ ' is from the manuscript, the one afterwards is from Mehmet Yaman Dede's translation. Where suitable, italics have been implemented to highlight the relevant alteration. 
A very obvious adaptation, of course, is the exchange of Ottoman Turkish words and expressions with equivalents from modern Turkish. On the one hand, Mehmet Yaman Dede often replaced loanwords from Arabic and Persian with synonyms of Turkish origin (e.g., evliyā > erenler, ġāyet > son, ța ām > yemek, see 1l. 7, 11, 16), but sometimes also with other Arabic or Persian loanwords (e.g., itmām > tamam, zīrā ki > çünkü, ammā > fakat, see ll. 10, 19). On the other hand, Mehmet Yaman Dede replaced Turkish words that are not in general use today (e.g., işideler > dinleyeler, değme > rastgele, see ll. 17, 20). In some cases, he also transferred idiomatic expressions from Ottoman Turkish into modern Turkish (e.g., kạadir oldığı/olduḳları deñlü > gücü yettiği kadar/güçleri yettiğince, see 11. 13-14, 17-18).

Most of the above adaptations made by Mehmet Yaman Dede can be observed among several Buyruk manuscripts in Ottoman Turkish, in which similar innovations already appear. In this regard, Arapgir-Çimen Buyruğu exhibits vocalisations, spellings and linguistic peculiarities that predate its time of copying, namely the early $19^{\text {th }}$ century. By preparing a faithful copy of the exemplar, its scribe preserved all these features, which indicates the period in which the text was composed. Analysing the same passage as our text sample from another Buyruk manuscript (MS 2, fol. 158 ), copied in Ocak Köyü in the 1890s, we find several changes similar to those made by Mehmet Yaman Dede: By writing the respective vowels, the labial vowel harmony is employed (e.g., 'ilminüñ > 'ilminiñ, bilmedüğin > bilmediğini) and the vocalisation of some words is updated (e.g., deñlü > deñli, içün > için). Furthermore, the abbreviated accusative is partly dissolved (e.g., edebin ve erkānın > edebini ve erkanı, bilmedüğin > bilmediğini), and though rarely, some rewording occurs (e.g., ża īf > fakīir, deñlü > ḳadar).

Even regarding layout and text structure, we observe differences between Buyruk manuscripts. For instance, in some copies the poems are arranged in continuous text and the interrogative sentences of the dialogue between Şeyh Safiyyüddin and Şeyh Sadreddin are not highlighted in red ink. Thus, we see such adaptations by Mehmet Yaman Dede as partly rooted in the manuscript culture he experienced in his early years and continued to study. He must have been aware of the differences between Buyruk manuscripts, in terms of text arrangement, language form or vocabulary, and he obviously saw no contradiction in making further adjustments in his publications. Mehmet Yaman Dede touched on this issue in an interview: 'In short, [Buyruk] is a fundamental book for Alevism. But, of course, some adjustments must be made to the Buyruk, it must be adapted 
to the time. Or better said, it must be reworked in a form appropriate to the times, without destroying its essence. ${ }^{85}$,

From this general statement it is hard to understand which adaptations Mehmet Yaman Dede had in mind. Judging from his translation work, however, he also included changes that went beyond general linguistic rewording. One could say that he aimed at harmonizing the Alevi written tradition with Alevi oral lore and cultural practices. In our text sample, we find an excellent example to illustrate how he attempted this. The selected passage finalizes the long text unit titled 'The Book of the Place of the Sacred Deeds [...]' and makes reference to exactly this text by phrases such as 'this book', 'these "Sacred Deeds", 'these "Deeds of the Saints", or "this "Book of Sacred Deeds"' (see Appendix 1, 11. 7, 10, 17, 19-20). At one point in the passage, Mehmet Yaman Dede added 'Buyruk' in parenthesis next to 'this book' and at other points he replaced 'Deeds' with 'Buyruk' (Appendix 2, 11. 7, 17, 19-20). He most probably did so, in order to finally introduce, or better inscribe, the orally prevalent title 'Buyruk' into these text collections, which have other titles in the respective manuscripts. Throughout his Buyruk publications, we see how he put 'Buyruk' next to the other titles or replaced the latter with 'Buyruk' ${ }^{86}$

Last but not least, Mehmet Yaman Dede made use of paratextual elements that had not been part of Buyruk manuscripts. Among other things, there are the table of contents, which lists the headings that he had assigned to passages of the prose text, and the two indices at the end of his last Buyruk publication. While the table of content facilitates navigation for readers who are interested in particular topics, the indices collect words and phrases with their meaning, which is in part peculiar to the Alevi tradition, and give brief information on the religious figures appearing in the text. For the latter, we can imagine how a dede would have made similar short explanatory excurses during his readings from a Buyruk, to supply additional or necessary information on the text.

\section{Conclusion}

The writings in Buyruks or other fixed texts such as the frequent orally transmitted songs and hymns existed side by side with, as yet textually unfixed knowledge that circulated within and among Alevi communities. A major part of

85 'Yani Alevilik'le ilgili temel bir kitap oluyor. Ama tabii Buyruğun üzerinde bazı düzenlemelerin yapılması gerekiyor. Çağa uydurulması, daha doğrusu çağa uygun bir şekilde, aslını bozmadan yeniden uyarlamak gerekiyor.' (Ayhan 2014b).

86 Cf. MS 1, fol. 20', with MAAKMDK 2000, 39. For another example, see Karolewski 2018, 85-86. 
the latter constitutes the interpretations of fixed texts, which had to be acquired in a non-written way, namely by attending educational meetings or rituals. For several centuries, at least, these interpretative, and also commentative, practices must have belonged almost exclusively to the domain of oral transmission. Thus, it is not surprising at all that there are no written interpretations or commentaries for Buyruk texts so far.

Mehmet Yaman Dede realised the need to fix the orally transmitted knowledge of his tradition in writing, which becomes most apparent in his textual additions to the Buyruk texts and content-related changes. His modifications in layout and text structuring, however, are clearly inspired by conventions of print publications, and the numerous adaptations to modern Turkish also mirror the long-term impact of the Turkish Language Reform, from its beginnings in the 1930s. Many strategies, however, that Mehmet Yaman Dede applied when adapting Buyruk copies to book publications are continuations and rearrangements of practices from the respective manuscript tradition. Other copyists and compilers before him adjusted texts while copying from one or more exemplars and they made both conscious and unconscious changes, whether in text structure, language or word choice. Thus, the textual transmission allowed for adaptations, and Mehmet Yaman Dede continued these practices to make the teachings from Buyruks understandable to Alevis of today.

\section{Acknowledgements}

We are profoundly grateful to Hülya Çelik of Ruhr-Universität Bochum whose informed comments and attention to detail have done much to improve this contribution. In addition, we thank Antonella Brita and Darya Ogorodnikova, both of Universität Hamburg, for reading and commenting on an earlier version of this contribution.

\section{List of Manuscripts}

MS 1

MS 1-XEROX

MS 2
(=Arapgir-Çimen Buyruğu): Dated 11 Rebiülahir 1241 AH (22 November $1825 \mathrm{CE})$. In private possession, bequeathed by M. Yaman. photocopy of Arapgir-Çimen Buyruğu with notes by M. Yaman, in private possession, bequeathed by M. Yaman.

(= Buyruk manuscript from Ocak Köyü Müzesi): Copied in Ocak Köyü. Dated 16 Eylül 1306 maliye (28 September 1890 CE), 13 Nisan 1309 maliye (25 April 1893 CE) and 1309 maliye (1893/1894 CE). Ocak Köyü Özel Müzesi, Ocak Köyü Kitaplığı, Inv.nr. 73. 


\section{References}

Aydın, Ayhan (2014a), 'Mehmet Yaman 2' [interview with Mehmet Yaman Dede, 1995, Istanbul], on Erenlerin İnsanlık Yolunda Ayhan Aydın (ed.), <http://ayhanaydin.info/soylesiler/ dedeler/66-mehmet-yaman-2> (accessed on 9 July 2019).

Aydın, Ayhan (2014b), 'Mehmet Yaman (3.)' [interview with Mehmet Yaman Dede, 24.12.2004, Istanbul], on Erenlerin İnsanlık Yolunda Ayhan Aydın (ed.), <http://ayhanaydin.info/ soylesiler/dedeler/67-mehmet-yaman-3> (accessed on 9 July 2019).

Aytekin, Sefer (ed.) (1958), Buyruk, Ankara: Emek Basım-Yayınevi.

Bausi, Alessandro (2010), 'A Case for Multiple Text Manuscripts Being “Corpus-Organizers”', manuscript cultures, 3: 34-36.

Berk Albachten, Özlem (2015), 'The Turkish Language Reform and Intralingual Translation', in Şehnaz Tahir Gürçağlar, Saliha Paker and John Milton (eds), Tradition, Tension and Translation in Turkey, Amsterdam / Philadelphia: John Benjamins, 165-180.

Bisâtî (2003), Şeyh Sâfí Buyruğu (Menâkıbu 'l-Esrâr Behcetü 'l-Ahrâr), ed. Ahmet Taşğın, Ankara: Pyramit Yayıncılık.

Boeschoten, H. E. (1988), 'Why Transcribe Ottoman Turkish Texts?', Manuscripts of the Middle East, 3: 23-26.

Borovalı, Murat and Cemil Boyraz (2014), 'Turkish Secularism and Islam: A Difficult Dialogue with the Alevis', Philosophy and Social Criticism, 40/4-5: 479-488.

Dressler, Markus (2005), 'Inventing Orthodoxy: Competing Claims for Authority and Legitimacy in the Ottoman-Safavid Conflict', in Hakan T. Karateke and Maurus Reinkowski (eds), Legitimizing the Order: The Ottoman Rhetoric of State Power, Leiden: Brill, 151-173.

Dressler, Markus (2008), 'Alevīs', in Gudrun Krämer, Denis Matringe, John Nawas, and Everett Rowson (eds), Encyclopaedia of Islam, THREE, vol. 2008-1, Leiden: Brill, 93-121.

Gölpınarlı, Abdülbaki (1963), Alevî-Bektâşî Nefesleri. Istanbul: Remzi Kitabevi.

Kaplan, Doğan (2010), Yazılı Kaynaklarına Göre Alevilik, Ankara: Türkiye Diyanet Vakfı. Kaplan, Doğan (2019), 'Defining Alevism via Written Texts: The Example of the "Alevi-Bektaşi Classics"', in Weineck and Zimmermann (eds) 2019, 97-126.

Karakaya-Stump, Ayfer (2010), 'Documents and Buyruk Manuscripts in the Private Archives of Alevi Dede Families: An Overview', British Journal of Middle Eastern Studies, 37.3: 273-286.

Karakaya-Stump, Ayfer (2012), 'Alevi Dede Ailelerine Ait Buyruk Mecmûaları', in Hatice Aynur, Müjgân Çakır et al. (eds), Eski Türk Edebiyatı Çalışmaları VII. Mecmûa: Osmanlı Edebiyatının Kırkambarı, Istanbul: Turkuaz Yayınları, 361-379.

Karolewski, Janina (2018), 'Discovering Alevi Rituals by Analysing Manuscripts: Buyruk Texts and Individual Notebooks', in Johannes Zimmermann, Janina Karolewski and Robert Langer (eds), Transmission Processes of Religious Knowledge and Ritual Practice in Alevism between Innovation and Reconstruction, Berlin: Peter Lang, 75-106.

Karolewski, Janina (2020), 'The Materiality of Alevi Written Heritage: Beautiful Objects, Valuable Manuscripts, and Ordinary Books', in Martin Greve, Ulaş Özdemir and Raoul Motika (eds), Aesthetic Dimensions of Alevi Cultural Heritage, Würzburg: Ergon, 175-211.

Kehl-Bodrogi, Krisztina (1997), 'On the Significance of Musahiplik Among the Alevis of Turkey: The Case of the Tahtacl', in Kehl-Bodrogi, Kellner-Heinkele and Otter-Beaujean (eds) 1997, 120-137.

Kehl-Bodrogi, Krisztina, Barbara Kellner-Heinkele and Anke Otter-Beaujean (eds) (1997), Syncretistic Religious Communities in the Near East: Collected Papers of the International 
Symposium "Alevism in Turkey and Comparable Syncretistic Religious Communities in the Near East in the Past and Present”, Berlin, 14-17 April 1995, Leiden: Brill.

Konar, A. Handan (2019), 'Elucidating or (Un)breaking the Chain? Intralingual Translations and Retranslations of Şeyh Galib's Hüsn ü Aşk’, in Özlem Berk Albachten and Şehnaz Tahir Gürçağlar (eds), Studies from a Retranslation Culture: The Turkish Context, Singapore: Springer, 27-39.

Lewis, Geoffrey (1999), The Turkish Language Reform: A Catastrophic Success, Oxford: Oxford University Press.

MAAKMDK (2000) = Mannheim AKM Dedeler Kurulu (ed.) (2000), Buyruk: Alevî Inanç, íbadet ve Ahlâk ilkeleri, text arrangement and translation from Ottoman Turkish to Turkish by Mehmet Yaman, Istanbul / Mannheim: s.n.

Massicard, Elise (2005), 'Alevism in the 1960s: Social Change and Mobilisation', in Hege Irene Markussen (ed.), Alevis and Alevism: Transformed Identities, Istanbul: ISIS Press, 109-135.

Olsson, Tord (1998), 'Epilogue: The Scripturalization of Ali-oriented Religions', in Olsson, Özdalga and Raudvere (eds) 1998, 199-206.

Olsson, Tord, Elisabeth Özdalga and Catherina Raudvere (eds) (1998), Alevi Identity: Cultural, Religious and Social Perspectives. Papers Read at a Conference Held at the Swedish Research Institute in Istanbul, November 25-27, 1996, Richmond: Curzon Press.

Otter-Beaujean, Anke (1997), 'Schriftliche Überlieferung versus mündliche Tradition: Zum Stellenwert der Buyruk-Handschriften im Alevitum', in Kehl-Bodrogi, Kellner-Heinkele and Otter-Beaujean (eds) 1997, 213-226.

Özkul, Derya (2015), 'Alevi “Openings” and Politicization of the “Alevi Issue” During the AKP Rule', Turkish Studies, 16/1: 1-17.

Pehlivan, Battal (1993), Aleviler ve Diyanet: Araştırma, Derleme, Röportaj, Istanbul: Pencere Yayınları.

Sarı̈nder, Refika (2005), 'Transformationsprozesse des alevitischen Cem: Die Öffentlichkeit ritueller Praktiken und Ritualhandbücher', in Robert Langer, Raoul Motika and Michael Ursinus (eds), Migration und Ritualtransfer: Religiöse Praxis der Aleviten, Jesiden und Nusairier zwischen Vorderem Orient und Westeuropa, Frankfurt a. M.: Peter Lang, 163173.

Schmidt, Jan (2019), 'How to Write Turkish? The Vagaries of the Arabo-Persian Script in Ottoman Turkish Texts', in Dmitry Bondarev, Alessandro Gori and Lameen Souag (eds), Creating Standards: Interactions with Arabic Script in 12 Manuscript Cultures, Berlin: De Gruyter, 131-146.

Schubel, Vernon (2010), 'When the Prophet Went on the Miraç He Saw a Lion on the Road: The Miraç in the Alevi-Bektaşi Tradition', in Christiane Gruber and Frederick Colby (eds), The Prophet's Ascension: Cross-Cultural Encounters with the Islamic Mirrāj Tales, Bloomington/Indianopolis: Indiana University Press, 330-343.

Seyyid Nizamoğlu [or Seyyid Seyfullah Kazım b. Nizameddin, d. 1601] (1976): Seyyid Nizâmoğlu: Hayatı, Eserleri, Dîvanı, ed. Adil Ali Atalay, tr. Mehmet Yaman, Istanbul: Can Yayınları.

Shankland, David (2003), The Alevis in Turkey: The Emergence of a Secular Islamic Tradition, London / New York: Routledge / Curzon.

Shankland, David (2005), 'The Buyruk in Alevi Village Life: Thoughts From the Field on Rival Sources of Religious Inspiration', in Gilles Veinstein (ed.), Syncrétismes et hérésies dans l'Orient seldjoukide et ottoman (XIVe-XVIIIe siècle) (Actes du Colloque du Collège de France, octobre 2001), Leuven: Peeters, 310-323. 
Şimşek, Mehmet (1993), Hıdır Abdal Sultan Ocağı: Doğu Anadolu'da Sosyal ve Kültürel Yönleriyle Örnek Bir Köyümüz, $2^{\text {nd }}$ extended edn, Istanbul: Cevahir.

Vorhoff, Karin (1998), 'Academic and Journalistic Publications on the Alevi and Bektashi of Turkey’, in Olsson, Özdalga and Raudvere (eds) 1998, 23-50.

Weineck, Benjamin and Johannes Zimmermann (2019), 'Introduction: Sourcing Alevism Between Standard, 'Canon', and Plurality', in Weineck and Zimmermann (eds) 2019, 21-58.

Weineck, Benjamin and Johannes Zimmermann (eds) (2019), Alevism Between Standardisation and Plurality: Negotiating Texts, Sources, and Cultural Heritage, Berlin: Peter Lang.

Yaman, Ali (2004), Alevilik'te Dedelik ve Ocaklar: Dedelik Kurumu Ekseninde Değişim Sürecinde Alevilik, ed. Cemal Şener, Istanbul: Barış Matbaası.

Yaman, Ali (2015), ‘'̇nanç Özgürlüğüne İlişkin Uluslararası Birikim ve Türkiye’de Din-Devlet İlişkileri Bağlamında Alevilik Sorunu’, in Yalçın Çakmak and İmran Gürtaş (eds), Kızılbaşlık, Alevilik, Bektaşilik: Tarih, Kimlik, Inanç, Ritüel, Istanbul: Iletiş̧im, 271-285.

Yaman, Ali (2016), 'Diyanet Vakfı'nca Yayınlanan Alevî-Bektaşî Klasikleri Üzerinden Diyanet ve Alevîlik Tartışmaları', in Süleyman Akkuş et al. (eds), Uluslararası Alevî-Bektaşî Klasikleri Sempozyumu, Sakarya Üniversitesi, 08-09 Kasım 2014, Sakarya, Ankara: Türkiye Diyanet Vakfı Yayınevi, 148-166.

Yaman, Mehmet (1994), Erdebilli Şeyh Safî ve Buyruğu, Istanbul: Ufuk Matbaası.

Yaman, Mehmet (2003), Alevilik'te Cem: Inanç - Ibadet - Erkân, Istanbul: Can Yayınları.

Yaman, Mehmet (2014), Hıdır Abdal Sultan ve Ocak Köyü, Istanbul: Cevahir Yayınları.

Yaman, Mehmet (2018), Türk Modernleşmesi'nde bir Alevi Ocakzade Dinbilimcinin Seyir Defteri, prepared for printing by Ali Yaman, Hausen (Wied): Alevi-Bektaşi Kültür Enstitüsü / Das Alevitisch-Bektaschitische Kulturinstitut e. V.

Yildiz [or Yıldız], Hatice (2017), Revisiting the Qizilbash-Alevi Tradition: In Light of SeventeenthCentury Mecmua Manuscripts, PhD thesis, Graduate Theological Union, Berkeley.

Yıldırım, Rıza (2012), 'Inventing a Sufi Tradition: The Use of the Futuwwa Ritual Gathering as a Model for the Qizilbash Djem', in John J. Curry and Erik S. Ohlander (eds), Sufism and Society: Arrangements of the Mystical in the Muslim World, 1200-1800, London: Routledge, 164-182.

Yıldırım, Rıza (2017), ‘A Genealogy of Modern Alevism, 1950-2000: Elements of Continuity and Discontinuity', in Tözün Issa (ed.), Alevis in Europe: Voices of Migration, Culture and Identity, London: Routledge, 96-114.

Yıldırım, Rıza (2019), 'The Safavid-Qizilbash Ecumene and the Formation of the Qizilbash-Alevi Community in the Ottoman Empire, c. 1500-c. 1700', Iranian Studies, 52/3-4: 449-483.

Yıldırım, Rıza (2020), Menâkıb-ı Evliyâ (Buyruk): Tarihsel Arka Plan, Metin Analizi, EdisyonKritik Metin, Istanbul: Yapı Kredi Yayınları. 


\title{
Appendix 1: Arapgir-Çimen Buyruğu
}

\author{
Source: MS 1, fol. $72^{\mathrm{r}} .^{87}$
}

\{7\} imdi evliyānıñ edebin ve erkānın biz bu kitāb içinde yazdık-kim muhibb-i \{8\} evliyā olan țālibler oḳuyub 'amel èdeler ve her oḳudukçça bu ża'īfi $\{9\}$ ḩayır du'ādan unutmayalar bir kişinüñ 'ömri Nūḥ peyġamber 'ömrince olsa $\{10\}$ bu menāḳı-ī şerífi yazub itmām èdemeyeler • zīrā ki evliyā menāḳıbınuñ \{11\} gaāyeti ve bāṭn 'ilminüñ nihāyeti yoḳdur bu deñlü oldığı dahi țāliblere \{12\} hemān bir irşād ecliçündür her şeyhe ve ḩalīf[e]ye ve pīreye lāzım olan \{13\} oldur ki az̄ine gèceleri oldukda çerāġın uyarub kādir oldıġı \{14\} deñlü Allāh riżāsıçün ve Muhammed 'Alī ve On İki Îmām Çehārdeh $\{15\}$ Ma'șūm-i Pākler ve geçmiş pīrler ve beşkademler [sic] rūḥıçün atası $\{16\}$ ve anası canıçün ța‘ām yedüre ve ța‘āmdan-șoñra cemā'at $\{17\}$ țag̉ılmadan bu evliyānıñ menāḳıbı oḳuna țālibler ve muhibbler işideler ḳādir $\{18\}$ olduḳları deñlü edebinden ve erkānından țutub 'amel èdeler $\{19\}$ kişi bilmedüğin bilmek lāzımdur • ammā erkān erenleri bu kitāb-i \{20\} menāḳıb-i şerīfi her kimüñ öñünde gerekse oḳumayalar ve değme kişilere $\{21\}$ vèrmeyeler ve göstermeyeler evliyā muhibbleri oḳuyalar

Thus $\{\mathrm{imdi}\}^{88}$, we wrote down the rules and customs of the saints $\{$ evliyā $\}$ in this book, so that the disciples who are friends of the saints \{evliyā $\}$ should read it and act in accordance with it, and whenever they read it, they should not forget to ask blessings for this weak one [i.e. the author or scribe of the book]. Even if someone has the age of Prophet Noah, they could not have written and finished \{itmām èdemeyeler\} these 'Sacred Deeds', • since \{zīrā ki\} the 'Saints' Deeds' have no finish \{g்āyet $\}$ and the inner knowledge has no end. Even being [only] this much, [the book] is just \{hemān\} a teaching for the disciples. What is necessary for each şeyh, each halife and each pire is this: They should wake their lamp on Friday \{āzinne\} nights, according to their capabilities \{kāandir oldıġı deñlü\} they should spend a meal \{ța'ām\} for God's approval, for the souls of Muhammad-Ali, the Twelve Imams, the Forty \{Çehārdeh\} Innocent as well as the passed away pirs and pişkadems and for the souls of their father and mother. And after the meal $\left\{t \operatorname{ta}^{\prime} a \bar{m}\right\}$, before the community falls apart, these 'Deeds of the Saints' should be read. The disciples and friends should listen \{işideler\} to it, according to their capabilities \{ḳādir olduḳları deñlü\} they should learn their rules and customs and they should act in accordance with them. It is necessary \{lāzım\} that someone knows what they do not know. $\bullet$ But \{ammā the masters of the rules [of the mystical path, or only its rituals] should not read this 'Book of Sacred Deeds' in front of anyone, they should not give it to as well as show it to random \{değme\} people and the friends of the saint(s) should read it.

87 Transliteration and translation are ours. For better comparison with the Turkish original, we prefer a quite literal translation. For a literary translation into English, cf. Ylldırım 2019, 467. 88 Here and in Appendix 2, these braces indicate, when different wordings in Turkish translate to the same English words or expressions. 


\title{
Appendix 2: Version of Mehmet Yaman Dede
}

\author{
Source: M. Yaman 1994, 124; and MAAKMDK 2000, $151 .{ }^{89}$
}

\{7\} Bunun için, erenlerin edeb ve erkânını biz bu kitabın (Buyruğun) içinde yazdık ki, erenlere $\{8\}$ muhib olan tâlibler okuyup, gereğince amel edeler ve her okudukça bu zaîfi $\{9\}$ hayır duâdan unutmayalar. Bir kişinin ömrü Nuh Peygamberin ömrü kadar olsa, $\{10\}$ bu MENÂKIB-I ŞERÎF'i yazıp, tamam edemezler. Çünkü, Evliya Menâkıbı'nın \{11\} sonu ve BÂTIN İLMİ'nin nihayeti yoktur. Bu denli olduğu da tâliblere $\{12\}$ ancak bir irşad içindir. Her mürşide ve halîfeye ve Pîr'e lâzım olan $\{13\}$ şudur ki:

Cuma geceleri geldikte çerağını uyarıp, gücü yettiği $\{14\}$ kadar ALLAH rızâsı için ve MUHAMMED-ALÎ ve ONIKİ İMAM ve ONDÖRT \{15\} MASÛM-İ PÂK'ler ve geçmiş pîrler ve beş kademler ruhu için, atası $\{16\}$ ve anasının canı için yemek yedire ve yemekten sonra cemâat \{17\} dağılmadan bu evliya'nın buyruğu okuna, tâlibler ve muhibler dinleyeler, güçleri \{18\} yettiğince edebinden ve erkânından öğrenip amel edeler. \{19\} Kişi bilmediğini öğrenmek gerektir. Fakat, erkân erenleri bu $\{20\}$ kutsal BUYRUK Kitabı'nı her önüne gelenin yanında okumayalar ve rastgele kişilere $\{21\}$ vermeyeler, göstermeyeler, yalnızca Erenlere muhib olanların yanında okuyalar.

Thus \{bunun için\}, we wrote down the rules and customs of the saints \{erenler\} in this book (Buyruk), so that the disciples who love the saints \{erenler\} should read it and act in accordance with it, and whenever they read it, they should not forget to ask blessings for this weak one [i.e. the author or scribe of the book]. Even if someone has the age of Prophet Noah, they could not have written and finished \{tamam edemezler\} these 'Sacred Deeds'. Since \{çünkü\} the 'Saints' Deeds' have no finish \{son\} and the inner knowledge has no end. Even being [only] this much, [the book] is just \{ancak\} a teaching for the disciples. What is necessary for each şeyh, each halife and each pir is this:

They should wake their lamp on Friday \{cuma\} nights, according to their capabilities \{gücü yettiği kadar\} they should spend a meal \{yemek\} for God's approval, for the souls of Muhammad-Ali, the Twelve Imams, the Forty \{Ondört Innocent as well as the passed away pirs and five feet \{beş kademler\} and for the souls of their father and mother, and after the meal \{yemek\}, before the community falls apart, this 'Command of the Saint(s)' should be read, the disciples and friends should listen \{dinleyeler\} to it, according to their capabilities \{güçleri yettiğince\} they should learn their rules and customs and they should act in accordance with them. It is necessary \{gerek\} that someone knows what they do not know. But \{fakat\} the master of the rules [of the mystical path, or only its rituals] should not read this sacred 'Buyruk Book' in the presence of everybody and they should not give it to random \{rastgele\} people, they should not show it, they should read it only in the presence of those who love the saint(s).

89 The respective line numbers of the manuscript have been inserted here to better facilitate comparison between both text versions. 

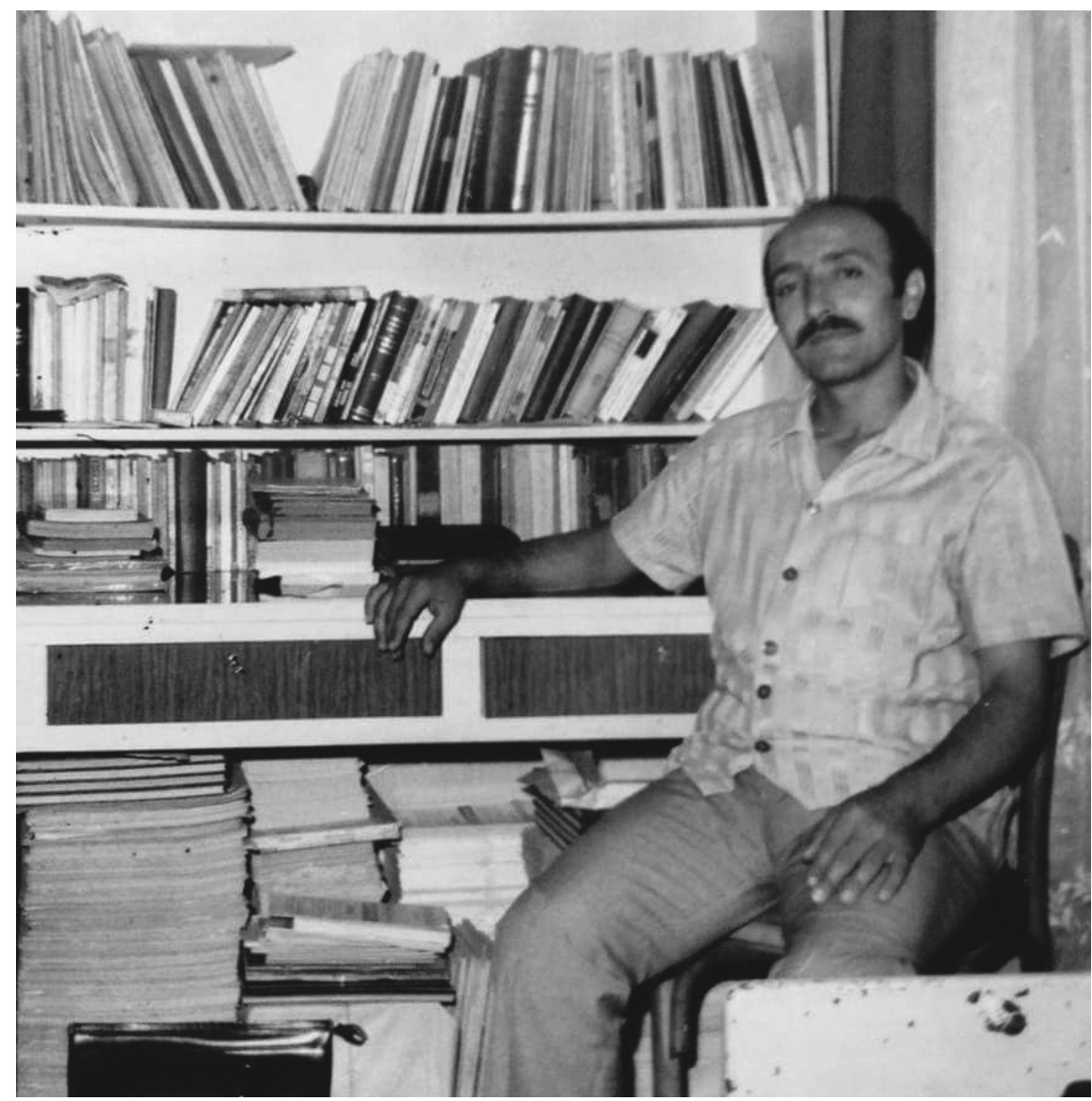

Fig. 1: Mehmet Yaman Dede, in front of his bookshelves. Istanbul, August 1976; @ Ali Yaman. 


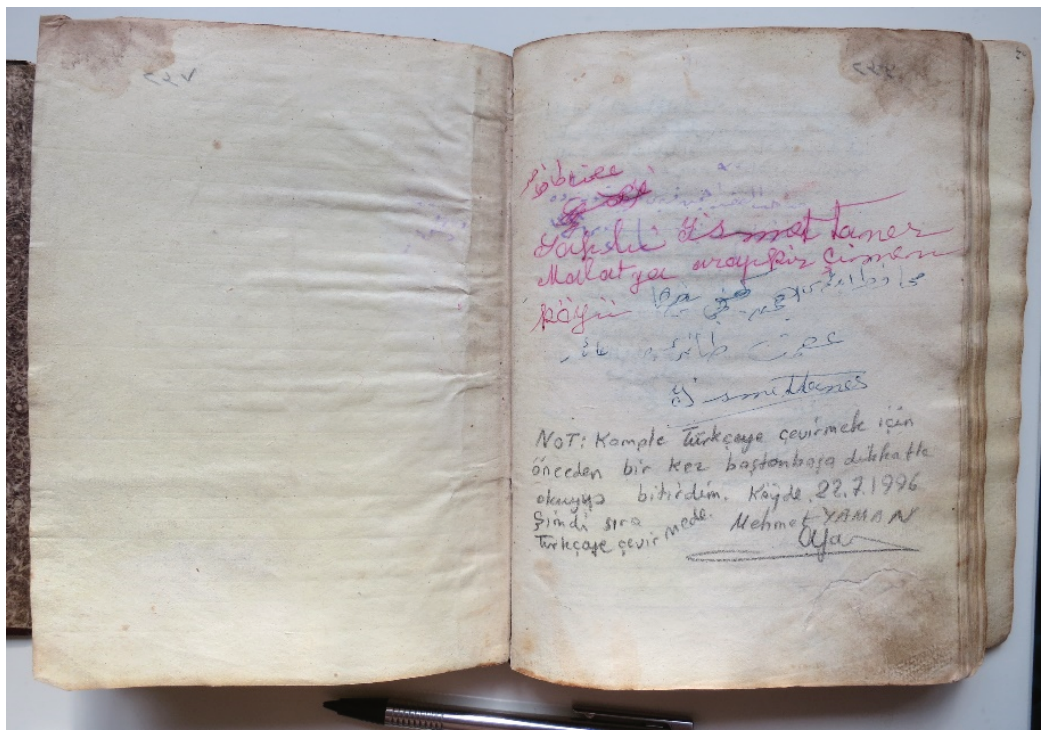

Fig. 2: MS 1, Arapgir-Çimen Buyruğu, fols $118^{v}-119^{r}$; @ Ali Yaman. Photograph by Janina Karolewski.

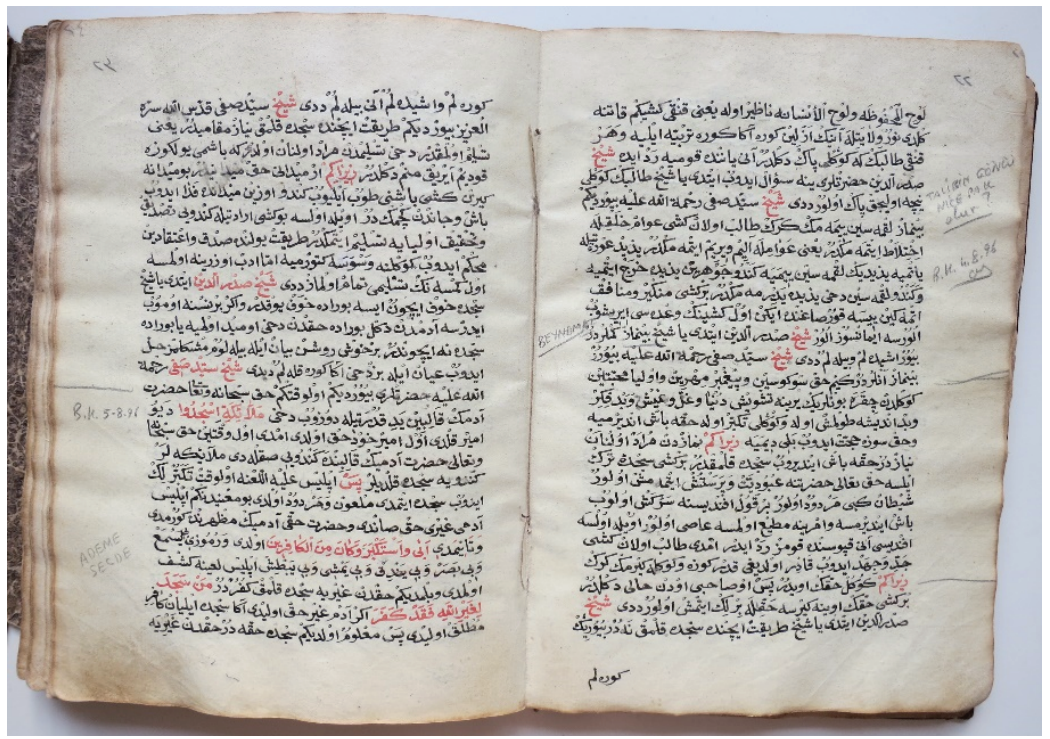

Fig. 3: MS 1, Arapgir-Çimen Buyruğu, fols $11^{\mathrm{v}}-12^{\mathrm{r}}$; (C) Ali Yaman. Photograph by Janina Karolewski. 


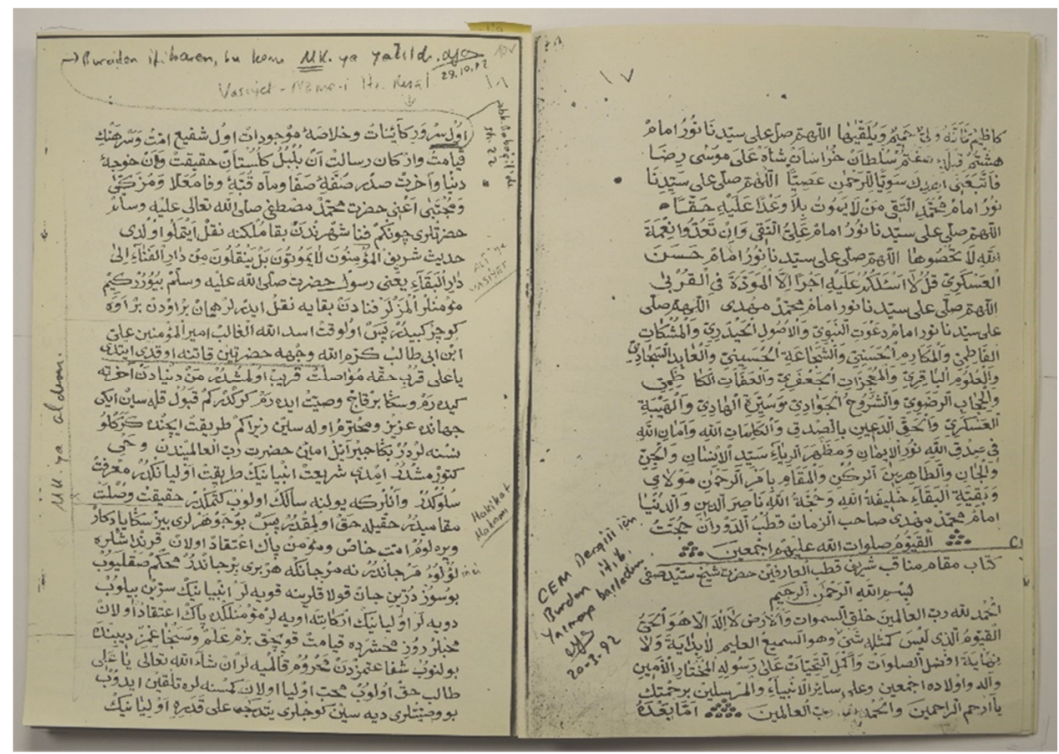

Fig. 4: Photocopy of MS 1-XEROX, Arapgir-Çimen Buyruğu, fol. $9^{\text {r-v }}$; ( Ali Yaman. Photograph by Janina Karolewski.

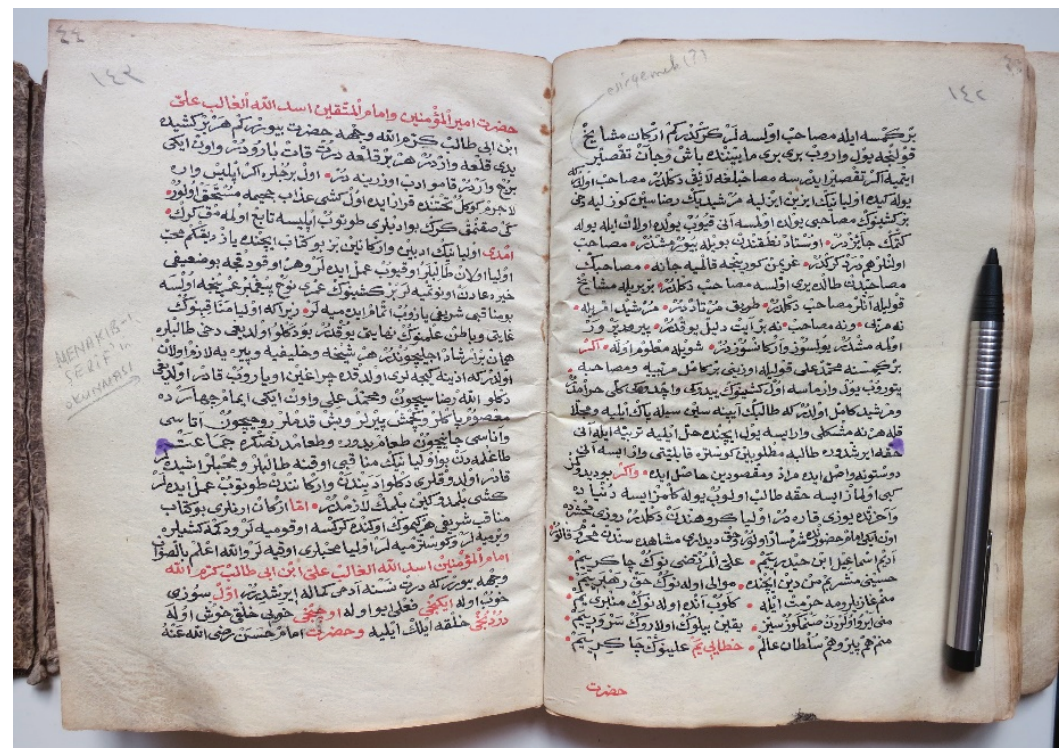

Fig. 5: MS 1, Arapgir-Çimen Buyruğu, fols $71^{\vee}-72^{\text {r; }}$ ( ) Ali Yaman. Photograph by Janina Karolewski. 


\section{MÜSÂHIBLERIN KARŞILIKLI GÖREVLERI}

șu halde músáhiblik dóvası (iddiasi) da böyledir:

Bir tâlib bir kimse lle músăhib olsalor, gerektir $k$ i, mürșidlerin buyrugunca yola gidip, birbirleri arosinda bas ve conlarinı esirgemeyeler. Eḡer esirgerlerse, müsahibliğe láyık değllidirler. Müsăhib şudur ki, yola gi de. Erenlerin izini izleye, mürșidinin razlığıinı gözleye. Ve de bir kişinin müsahibl yoldan çiksa onun birakıp, yolda olanla yola gitmesi uygundur. üstad nutkundan bỏyle buyurmuştur.

Müsahib olanlar, birbirinir derdiyle dertlenmeli, ilgilenmelidir.

$$
\text { "Müsôhib olanlar hem-dert gerektir. }
$$

Müsóhilbin mũsâhibden dalda (gizli) yeri olsa, mūsâhib değildir; mūrtșidlerin kavli bóyledir. Bōyle olan müsóhibin yolu murtad (yoldan-et-

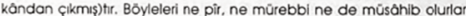
tâlibi eğltemezler, yolsuz ve erkônsizdirlar. Surasi iyi bilinmelidir ki:

Eḡer bir kimse. MUHAMMED-ALî kovliyle, ozzūnū bir kâmil mürebblye ve müsóhibe bag̉layp. yole gitmese, o kişinin yediği ve içtiği tưmüyle haramdir.

Mürșid-i kâmil șudur $k$ :

Iolibin Gyinesini (gönlũnü) silip temizleye ve pirll pinl eyleye; her ne sorunu varsa yol içinde (Buyrugáa, erkôna uygun olarak) çözūmleye, terblye (eğitim) ile onu Hokk a (ve gerçeǵe) eristire: tollibe matlubun (dilediğini, gerçekler yolunda istediği seyleri, bilglleri) góstere; yeteneğ varsa. tôlibi sevdiğine eriștie: gónlündeki muradinı ve dileğin hasıı ede...

Ve eger bu dediğimiz gibi olmazsa. Hakk a tâlib olup. yola gelmezse, dûnyada ve ôhirette yưzũ karadir, Erenler zümresinden değlidir, mahşer gününde ONIKI IMAM EFENDILERIMIZ 'n huzurunda mahcup (utanmıs, hacil) olur ve HAKX'in DiDARl'n gobrmekten mahrum kolr.
BUYRUK

\section{HAK REHBERIYIM}

-Adım Ismáil-übni Hayderiyem Aliyyel-Mürtezâ'nin çâkeriyem Hüseynî meșrebin ben đîn içinde Mevâi olanin Hck rehberiyem

Benim gázilerime hürmet eyle Gelüp anda olanin minberiyem

Beni ayn onlardon sanmanuz siz Yakin bilin onlarn serveriyem Benim hem pîr ve hem sulț̂n-ı ôlem HATÂYî̀yem ALL'nin çákeriyem.

Havret-1 Emîr-el-Mü'minin ve Imam-ül-Müttekin, Esedullah-ül-Gâli Ail b. Ebo Tollib Kerrem-Allanũ veche buyurur $k$

Her bir kiside yedi kal a varcr. Her bir kal a dor kathisar buiccy

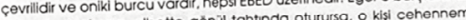
lis (seytan) girerse, elbette gönul tantinda olulusa, o kis conis cikmo ateşine müstahak olur. Çok sakinmak gerek, bu edeplere sohip çikmahi, iblise uymamalidir."

Bunun lin Bunun için, erenlerin edeb ve erkanin blz okuyup, gereğince amel de yazdik ki, erenlere muhib olan tabler ok untmayolar. Bir kişinin edeler ve her okudukça bu zairi hayr duadan Un ömrü Nun Peygamberin ômrũ kodar olso, bu MENÂKIB-I SERRF l yazip.

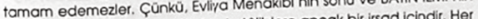
tingreti yoktur Bu denli olduğu da táliblere ancak bir irşad içindir. Her mürside ve haffeye ve Pir' lo lozm olan şudur ki:

I Cuma geceleri geldikte cerağinı uyañ. gúc yettigi kador ALLAH nzası için ve MUHAMMED-ALI ve ONIKI IMAM ve ONDCRT MASOMPÁK'ler ve geçmiş pîrler ve beş kademler ruhu iç cani lcin yemek yedite ve yemekten sonra cemaat daginadan bu evilyo'nn buyugu okuna, talibler ve muhibler aineyeler. guclen yettievilyán buy verkanindan ógrenip amel edeler. Kiși bilmediğin gince edebinden ve ekat, erkćn erenleri bu kutsal BUYRUK Kitabi'nu her ogrenmek gerekir. Faka okumayalar ve rostgele kişlere vermeyeler. onüne gelenin yaninda okumar muhib olanlarin yaninda okuyalar.

Fig. 6: MAAKMDK (2000), Buyruk, pp. 150-151; @ Janina Karolewski. 
